\title{
Transfer Pricing for Intangibles: Problems and Solutions from Colombian Perspective
}

\author{
JuAn Carlos Díaz García*
}

Contents: I. Introduction. II. Transfer Pricing. 1. Definition. 2. Origin. III. Arm's Length Standard. 1. Definition. 2. Origin and International Adoption. i. The United States. ii. OECD and International Adoption. iii. Colombia. IV. Criticism of Arm's Length Standard and its Relation with the Income Shifting. 1. What is Income Shifting? 2. Why The Arm's Length Standard Cannot Avoid MNEs' Income Shifting? V. BEPS Solutions. 1. Why BEPS for transfers pricing for intangibles? 2. The OECD action plan. i. Action item 1 ("Address the Tax Challenges of the Digital Economy"). ii. Action items 8 ("Assure that Transfer Pricing Outcomes Are in Line With Value Creation"). iii. Action item 13 ("Re-examine Transfer Pricing Documentation"). 3. OECD releases implementation package for BEPS CountryBy-Country reporting. VI. Proposition of alternative tools.1. Formulary apportionment approach. 2. Recharacterizing intra-group equity investments as a type of long-term subordinated debt.VII. Conclusions. VIII. References.

\begin{abstract}
This article assesses that tax administrations- likewise the Colombian tax authorityhas been facing difficulties to audit transfer pricing transactions with intangibles, because the current transfer pricing rules are not adapted to the new digital economy or e-commerce cross borders transactions. Therefore, the MNEs take advantage of the flexibility of the transfer pricing rules reducing their tax liability by income shifting using intangibles. The article analyzes the income shifting practices using intangibles, and the reasons why the arm's length standard does not work well at all and cannot avoid appropriately MNEs' income shifting and base erosion.
\end{abstract}

\section{Introduction}

The Colombian Minister of Finance, Mauricio Cardenas, aforesaid that tax evasion affects the ability of governments to work for the welfare of their citizens; he reiterated the importance for developing countries of

\footnotetext{
* Abogado de la Universidad Externado de Colombia. Máster en International Taxation de UF Levin College of Law. Gainsville (Florida). To cite this article: Díaz, J. C. (2016). "Transfer Pricing for Intangibles: Problems and Solutions from Colombian Perspective". Revista de Derecho Fiscal n. ${ }^{\circ}$, Bogotá: Universidad Externado de Colombia. pp. 103-123. DoI: http://dx.doi. org/10.18601/16926722.n8.08
} 
fighting against tax evasion (OECD, Ministerial Council Meeting, 2015). The significance of transfer pricing and its impact on the tax collections of tax administration has brought this subject to the forefront of international tax debates. Basically, the governments of countries involved in expanding international trade are competing with each other to allocate taxable profits of MNEs into their jurisdictions (Lowell \& Briger, 2014).

The multinational enterprises ("MNEs") embody a large proportion of global Gross Domestic Product, and the intra-firm trade represents an increasing proportion of overall trade (OECD, Action Plan on Base Erosion and Profit Shifting, 2014). The arm's length standard literature demonstrates that the weakness of all transfer pricing regimes includes intangible related transactions and debt financing, yet this paper is focused in more detail on the study of the intangible transactions and their implications in the tax avoidance.

The intangible property is mostly important for MNEs as they obtain a significant portion of their income from it. The current transfer pricing rules are not properly adapted to the new digital economy as they were not designed to regulate intangibles or e-commerce cross borders transactions (Brauner, What the Beps?,2014). Under the arm's length regime the valuation of intangibles results in high level of compounded inaccuracy (Brauner, 2008). The MNEs take advantage of the flexibility of the transfer pricing rules reducing their tax liability by income shifting (Noked, 2014), which could be defined as the way in which MNEs legally reduce their tax liability locating profitable functions and accumulating income in low tax jurisdictions.

The Colombian tax authority, Directorate of National Taxes and Customs, hereinafter
DIAN, has been facing difficulties to audit transfer pricing transactions, likewise other national tax administrations. The Base Erosion and Profits Shifting projects ("BEPS") provide governments with new tools to battle against tax avoidance such as "Country-ByCountry Reporting".

Colombia has adopted the arm's length standard in its national legislation. The third principle of BEPS states the concern about innovative solutions even when they conflict with the traditional premises of the current international tax regime. For that reason, this paper analyzes, first, the actions established specifically for intangibles in BEPS, and, second, some of the solutions provided by the literature, which are in accordance with the international accepted principle arm's length standard.

In this paper we prove that all solutions to be raised in Colombia against income shifting must be done from the OECD frameworks, since there is precedent of the Colombian Constitutional Court to recognize the guidelines of the OECD as auxiliary criteria of interpretation. Moreover, the solutions proposed in the literature also should be analyzed from the arm's length standard.

The paper proceeds as fallow: Part I sets the definition and the origin of transfer pricing rules so as to explain the reasons of their importance in the international tax system.

Part II analyzes the definition, origin and international adoption of the arm's length standard rules in turn to demonstrate what the role that Colombia plays in the international tax community is and why the DIAN's approaches to fight against tax avoidance and base erosion behaviors should come from the arm's length standard and the OECD's transfer pricing guidelines and frameworks. In this part, it will be confirmed that the 
implementation of the arm's length standard in Colombia is a result of its international development, and the reasons why the DIAN must remain applying the OECD's transfer pricing frameworks will be explained.

Part III analyzes the income shifting practices using intangibles, and the reasons why the arm's length standard does not work well at all and cannot avoid properly MNEs' income shifting and base erosion. These situations propitiated the current international environment of awareness of the requirement to implement new practical anti-tax avoidance tools.

The theoretical analysis of the income shifting practices is followed by the solutions provided by the OECD in BEPS to fight against tax avoidance using intangibles in Part IV. The OECD come with a new approach, and its new instrument is the "Country-By-Country Reporting", which will be useful for the DIAN to improve its audit procedure and the compliance of MNEs taxpayers. Similarly, the reporting will be helpful to achieve a comprehensive analysis of the information provided by multinationals.

Although Colombia must remain in the OECD frameworks, the paper finalizes, in Part V, with the consideration of additional solutions against income shifting and base erosion behaviors, which came from outside of the traditional perspective of the OECD. Implementing these alternative tools by DIAN would happen after a thorough study of their convenience from the legal and economic points of view. Firstly, the formulary apportionment approach, which its proponents argue that, would reduce MNEs ability to use transfer pricing to locate their taxable income in low-tax countries (Morse, 2010). Finally, the possible inclusion of a methodology such as recharacterizing intra-group equity investments as a type of long-term subordinated debt.

\section{Transfer Pricing}

\section{Definition}

Transfer pricing refers to the pricing of transaction between related entities for goods, services, intangible property, rents and loan. The transfer pricing determines the division of total profit between the related entities. As market forces do not certainly control transactions prices within a related group, several countries have enacted transfer pricing rules and improved enforcements efforts to prevent the use of transfer price to shift income of their tax jurisdiction. However, transfer pricing rules are complex in their application and non-uniform, usually resulting in compliance difficulties on a global basis (Levey \& Wrappe, 2013).

Currently, transfer pricing plays an important role in an international tax system. One of the most significant current business and tax concerns for MNEs it is the way in which prices assets, such as the results of research and capital transferred to their related entities. The transfer pricing policies and practices used in connection with the transfer of goods, services, and intangibles from one affiliated corporation to another across borders have more impact on which governmental jurisdiction taxes the income generated from international transactions than any other aspect of the tax law (Lowell \& Briger, 2014).

\section{Origin}

Transfer pricing was firstly created as a managerial accounting concept in the U.S, 
instead of a tax concept. The transfer pricing could be traced back to the nineteenth century, when some companies devolved into multi-segment businesses, in which managers were faced with the need to price intercompany transactions to better reflect the profitability of each segment and maximize the overall profitability of the firm. Coherent with this accounting point of view, transfer pricing is defined as "the amount charged by one segment of an organization for product or service that it supplies to another segment of the sane organization (Levey \& Wrappe, 2013)."

With the rise of MNEs, developing a mechanism to clearly reflect the income attributable to controlled entities under different national jurisdictions to prevent tax avoidance and double taxation was needed from the tax law perspective. To achieve it, the tax authorities have adopted the transfer pricing concept to guarantee that they are taxable on the true taxable income in each tax jurisdiction. Without transfer pricing rules, MNEs could be permitted to use transfer pricing to shift large amounts of income from one tax jurisdiction to another (Levey \& Wrappe, 2013).

\section{III.Arm's Length Standard}

\section{Definition}

The arm's length standard requires that intercompany prices be set as if the related parties were independent unrelated parties. For many decades, governments and taxpayers have struggled to define the arm's length standard in actual operations (Lowell \& Briger, 2014). In this subchapter, we clarify the definition of the arm's length standard adopted by the U.S regulations, OECD Model
Tax Convention and Colombian legislation in order to determine if the standard is applicable by the same way in the three normative bodies. However, we should keep in mind that Colombia must remain in the OECD's transfer pricing frameworks.

In the United States, the first definition of the arm's length standard is not included in the text of Internal Revenue Code (Section 482), yet it has been included in Treasury Regulation since 1935, which has been the basis of the development of all transfer regulation since that time (Levey \& Wrappe, 2013). The arm's length standard requires that a controlled taxpayer realizes the same results from their controlled transactions as would have been realized if an uncontrolled taxpayer had engaged in the same transaction under the same circumstances. (Treas. Reg. § 1.482-1 (b)(1)).

On the other hand, the article 9 of OECD Model Tax Convection, defines arm's length standard as [When] conditions are made or imposed between (...) two enterprises in their commercial or financial relations which differ from those which would be made between independent enterprises, then any profits which would, but for those conditions, have accrued to one of the enterprises, but, by reason of those conditions, have not so accrued, may be included in the profits of that enterprise and taxed accordingly (OCDE, Transfer Princing Guidelines, 2010). This article and almost all tax treaties of the United States, which contain articles in transfer pricing (in the associated enterprise articles) implicitly endorse the arm's length standard, although the term is not actually used (Lowell \& Briger, 2014).

The arm's length prices "is the assumption that each affiliated company within the group transacts with the other members 
of the group in the same way that it would transact if the members were unrelated. ( Avi-Yonah, Clausing , \& Durst, 2009)". The arm's length standard is, in some extent, a fiction, in that attempts to measure the value of a transaction "as if" the parties had dealt with each other in an unrelated third party transaction. The OECD Transfer Pricing Guidelines are generally consistent with the U.S. transfer pricing regulations. The problems with the arm's length standard arise, among others, because it ignores certain efficiencies and economies of scale from operating related business that would not exist if the parties were not related (Levey \& Wrappe, 2013).

As the same approach as OECD and the U.S. legislation, the Colombian Tax Code defines the arm's length standard as "in which a transaction between related parties fulfill the conditions which would have been utilized in comparable transactions with or between independent parties. In this framework, as we see below, Colombia is no stranger to the international context in the application of the arm's length standard, and its Tax Administration may be facing the same difficulties with the enforcement of the standard, and then she should make an additional effort to provide clear rules related to the application of transfer pricing, and its use for MNEs to shift income in the Colombian tax jurisdiction.

\section{Origin and International Adoption}

\section{i. The United States}

In words of Professor Avi-Yonah, "Transfer pricing manipulation is one of the simplest ways to avoid taxation" (Avi-Yonah , The rise and Fall of arm's length: A study in the evolution of U.S. international taxation, 1995). In consequence, the predecessors of section 482 of the Code (Lowell \& Briger, 2014) were "designed to combat such manipulation, date back almost as far as the modern income tax itself" (Lowell \& Briger, 2014). (Yonah,1995) The arm's length language has never been included in the statutory language of Section 482, neither in its beginning with the War Revenue Act of 1917, Section 240 of the Revenue Act of 1921, 7 and Section 45 of the Revenue Act of 1928 (Section 45).

The arm's length language first arose in the initial regulations published under Section 45 of the Revenue Act of 1928 in 1935 (actually, then Section 45 of the Revenue Act of 1934) (Lowell \& Briger, 2014). The statutory predecessor to Code Section 482 was enacted in 1928, allowing broad authority to the Commissioner of the IRS to allocate gross income, deductions and credits and other items between and among controlled taxpayers in order to prevent, in part, because of the tax avoidance opportunities afforded by possession corporations, which were ineligible to file consolidated returns with their domestic affiliates. Subsequently, in 1934, regulations applying arm's length standard as a method of reallocation under the predecessor to Code Section 482 were issued (Avi-Yonah, The rise and Fall of arm's length: A study in the evolution of U.S. international taxation, 1995). For thirty-five years, until 1968, there were no significant changes made to U.S.transfer pricing rules, when the IRS promulgated comprehensive regulations that restated that the arm's length standard is the basic guiding principle of all the transfer analyses and described specific pricing methods to test the arm's length nature of transfer pricing (Levey \& Wrappe, 
2013). The arm's length standard was ratified in the 1993 proposed regulations and in the 1994 final regulations.

In the Revenue Act of 1962 the House of Representatives proposed a formulary approach similar the one which is used for the multi-state income apportionment in the U.S. The proposal was intended to arrange the difficulties of transfer of business activities by U.S. companies to their subsidiaries in low-tax jurisdictions. The proposal nonetheless was not enacted, it was important as the Treasury was invited to re-examine its existing regulations with particular focus on guidelines and formulas for the allocation of income and deductions (Levey \& Wrappe, 2013).

\section{ii. OECD and International Adoption}

The OECD first issued its transfer pricing guidelines in 1979. In 1995 and again in 2009, the OECD substantially revised its Guidelines in Transfer Pricing Guidelines for Multinational Enterprise periodically. The OECD's guidelines are based on the principles concerning taxation of multinational enterprises that are incorporated in the OECD Model Tax Convention. As we said before, the arm's length standard has been adopted by the OECD, under the believe that the standard provides the closest approximation of the working of the open market where goods and services are transferred between related parties (Levey \& Wrappe, 2013). Contrary, the Guidelines conclude that global formulary apportionment approach is not a no legitimate or realistic alternative to the arm's length standard. The global formulary apportionment approach is discussed in Chapter I of the guidelines, as follows: Global formulary apportionment, sometimes mentioned as a possible alternative, would not be acceptable in theory, implementation, or practice. (OCDE, 2010).

The OECD countries have used the arm's length standard in their formulation. Furthermore, the standard has been almost universally adopted as the international pricing standard, and has been adopted by the legislative or regulatory bodies in most other countries, in which Colombia is included (Lowell \& Briger, 2014). The result of the global enforcement environment makes transfer pricing one of the main areas for MNEs enterprises with taxpayers designating more resources to effectively address transfer pricing planning, compliance, and audits by tax authorities (Levey \& Wrappe, 2013).

The fact that the arm's length standard should be the international pricing touchstone does not appear to be under any grave dispute, while in the United States the manner of determining whether the standard has been satisfied has been the subject of intense debate in the past few years (Lowell \& Briger, 2014). Respected international tax scholars and former Treasury officials have concluded that the arm's length standard is simply unworkable and thus concluded that any proposed solutions to the HI/BEPS (Well \& Cym, 2014) problem must come from outside of the arm's length standard (Mundstock, 2012) (Morse, 2010) and (Altshuler \& Grubert, 2010). Nevertheless, accordingly to the current Colombian legislation and its international context, the solutions would come inside the arm's length standard, and these solutions should be in accordance with the OECD Transfer Pricing Guidelines.

According to the opinion of Bret Wells \& Cym Lowell "The mere existence of the 
HI/BEPS problem itself could be viewed as providing sufficient evidence for a prima facie case that the arm's length standard is deficient. MNEs argue that their tax planning and use of low-tax foreign subsidiaries "comply with U.S. and foreign tax laws." Legislators and scholars alike respond that the existence of the HI/BEPS problem provides compelling evidence that the arm's length standard does not and cannot defend against inappropriate income shifting to tax havens." Nonetheless, the tax authorities likewise DIAN, are obligated to find alternative and practical tools to fight against income shifting practices as soon as possible.

\section{iii. Colombia}

In comparison to the U.S., the Colombian legal transfer pricing tradition is almost recent as the first code sections related with this matter were just promulgated until 2002 by the Congress of the Republic. (Gazette No. 45, 046, 2002). Afterward, the first version of the Chapter XI of Title I of the Tax Code, which contains the code sections of transfer pricing rules from Article 260-1 to 260-11, was newly modified in 2012 upholding the same principles previously enacted. (Law 1607 of 2012).

As we saw before, Colombia has adopted the arm's length standard in Article 260-1 to support fiscal relations between MNEs and foreign tax administrations in the area of transfer pricing (DIAN, 2012). The OECD Transfer Pricing Guidelines are legally recognize as auxiliary criteria of interpretation by the Constitutional Court. (Decision C-690 of 2003) In that sense, the OECD Guidelines are mandatory frameworks that taxpayers and the DIAN must follow to accomplish the legal transfer pricing require- ments. Therefore, all possible solutions and internal reforms attacking income shifting and tax avoidance practices would be explored and enacted accordingly to the arm's length standard, in order to be agreed with the judicial decision of the Constitutional Court and the OECD policies.

As the same approach as the OECD Transfer Pricing Guidelines, which are consistent with the Code Section 482 regulations (Levey \& Wrappe, 2013), the Colombian rules state the elements to apply the arm's length standard as well, as fallow:

- Factors determining the comparability are described in Article 260-4 (characteristic of property or services, functional analysis, contractual terms, economic circumstances and business strategies).

- Arm's length range (OECD, Transfer pricing Guidelines for multinational Enterprises and Tax Administration, 2010) is define in Article 260-3 of the Colombian Tax Code and Article 8 of Decreto 3030 of 2013 (Decreto 3030 of 2013, article 8). Consistent with Code Section 482, the OCDE Guidelines state that if the taxpayer cannot show that the result of the related party transaction falls within the range, and adjustment should be made to any point within the arm's length range.

- Use of transfer methods is explained in Article 260-3 of the Colombian Tax Code. In contrast with the Code Section 482, the OCDE Guidelines and Colombian law do not require either the tax examiner or the taxpayer to perform analyses under more than one method or prove that the particular method does not apply (e.g. there is no best method rule.) (Levey \& Wrappe, 2013)

Likewise the OECD in its Guidelines, the DIAN argues in its Transfer Pricing Guidelines that the application of arm's length promotes the growth of international trade 
and investment making equitable tax treatment to MNEs and independent enterprises, since related and unrelated companies are in equal conditions for tax purposes, avoiding the creation of any advantage that could distort the competitive position of any firm. Moreover, the Tax Authority concludes that the purpose of the transfer pricing regime is offset the artificial prices that may occur between related entities to prevent the transfer of profits from hightax level to low-tax jurisdictions or tax havens (DIAN, 2012). Nonetheless, these arguments appear ingenuous and lack of accuracy in the contemporary international context, which has been analyzed by scholars who conclude that the arm's length standard does not successfully benchmark transactions within multinational companies (Avi-Yonah, Clausing, \& Durst, 2009). Similarly, BEPS recognize that the aggressive transfer pricing is their beating heart (Brauner, 2014), and its third principle is the adoption of innovative solutions against base erosion and income shifting (OECD, Action Plan on Base Erosion and Profit Shifting, 2014).

A comprehensive analysis of the Colombian transfer pricing legislation is beyond the scope of this paper, yet it is important to remark that these transfer pricing rules introduce a significant impact in the quantification of the companies income tax, as intragroup debts, costs and deductions are not subject to the limitations of cost and deductions established regularly on related parties. Article 124-1 of Colombian Tax Code states that interests payable to parent companies from Colombian subsidiaries are not deductible, however, upon a transaction is regulated by transfer pricing norms, the subsidiary is able to take the interest deduc- tion at arm's length, which open a great opportunity for aggressive tax planning.

Additionally, it is substantive observable that Colombian transfer pricing legislation lacks of any anti avoidance rule exclusively for intangibles, such as the "commensurate with income" of Section 482 and 367(d) or from a different approach. Nonetheless, instead of having special rule to attack the possible tax avoidance behaviors with intangibles by MNEs, we have enacted a regulation for cost sharing agreements, (Decreto 3030 of 2013, article 6) which are "generous" to tax payers (Brauner, 2014). The Colombian Tax Administration is not completely aware of the aggressive tax practices that MNEs might do with intangibles, and a prompt response is absolutely necessary.

Article 319-2 of the Tax Code states that all intangible contributions to companies or other foreign organizations shall be reported in the proxy statement transfer pricing, regardless of the amount of the contribution. The regulation (Decreto 3030 of 2013.), says that the contributions in kind and contributions in industry by natural persons, legal entities or Colombian entities or other entities shall be considered as a sale to foreign entities for tax purposes, which will be subject to transfer pricing regime. Consequently, the questions that arise from the previous rules are: first, what should the tax approach to evaluate properly the deemed sale of the intangible be?; Second, what should the treatment and the quantification of the future royalties from transferred high-value intangibles such as patents, copyrights, trademarks, and unpatented know-how be? -Commensurate with income from the U.S. perspective.

Besides, in my opinion another problematic issue is the proper valuation of 
the intra-group royalties that are payable from Colombian entities to their related foreign entities for the use of licensed intangibles, which are characterized as deduction and cost. That common practice might be a simple manner to erode the income tax base. In the literature, a customary alternative answer different from the arm's length standard to solve the difficulties to valuation of intangibles is the formula-based regime or formulary apportionment (Avi-Yonah \& Benshalom, 2011). In addition, one the OECD's solutions is the country-by-country reporting (OECD, Country-by-Country Reporting Implementation Package, 2015). Those solutions will be analyzed in Chapter IV and $\mathrm{V}$ of this paper.

\section{Criticism of Arm's Length Standard and its Relation with the Income Shift- ing}

Currently, policymakers, theorists, and practitioners consider the arm's length standard based transfer pricing the most critical problem in international taxation and in the income taxation of MNEs' income. This is a consequence of the intrinsic deficiency of the arm's length standard in breaking down related-party transactions and the manner in which this difficulty plays out in the more complex tax-competition dynamic between countries and investors (Benshalom, 2013).

\section{What is Income Shifting?}

In its basic form, income shifting is a manner in which MNEs legally reduce their tax liability, when they locate profitable functions and accumulate income in low tax jurisdic- tions - as Ireland, Luxembourg and other known jurisdictions - for purpose of tax avoidance, whereas conducting the fewer profitable activities and reporting little expenses in high-tax jurisdictions -as much The United States-. Commonly, intellectual property income shifting generally involves the transfer of intellectual property through a sale, licensing, or a cost-sharing agreement, which is, for instance, as result of an agreement between the U.S. parent and a subsidiary or an affiliate to share the costs of developing an intangible. Intellectual property income shifting represents a large portion of the overall income-shifting tax planning (Noked, 2014).

For tax reporting purposes each corporation within the MNE group, which is a separate legal entity that can freely contract with other entities, should keep separate books and be taxed only on its income, and then each corporation needs to allocate the profits derived from related transactions to the contractual setting designed by the MNE. Therefore, under separate accounting, each independent structure of intra-group transactions should be respected, yet intra-group transactions among MNE affiliates should be priced as if made with unrelated parties -at arm's length (Noked, 2014).

The arm's length standard creates a clear incentive to earn profits in low-tax countries - from the Colombian perspective such as Panama, and recently other countries of Central America-. MNEs locate real activities (jobs, assets, production) in low-tax countries, and then, respond with various legal and accounting techniques to shift profits to these low-tax locations, disproportionately to the scale of business activities in such locations (Avi-Yonah \& Benshalom, 2011). 
Prof. Reuven S.Avi-Yonah provides some examples of MNEs income shifting performs, as fallow:

There are multiple such ways to shift income to subsidiaries in low-tax countries. For example, it may be advantageous for multinational firms to alter the debt/equity ratios of affiliated firms in high and lowtax countries in order to maximize interest deductions in high-tax countries and taxable profits in low-tax countries. [...] For example, firms can follow a strategy of under- (over-) pricing intra-firm exports (imports) to (from) low-tax countries, following the opposite strategy with respect to high-tax countries. The most powerful of such techniques typically involve the transfer of interests in intangible property, such as patents, copyrights and trademarks as well as unpatented know-how, to subsidiaries in low-tax countries. (AviYonah \& Benshalom, 2011)

\section{Why The Arm's Length Standard Can- not Avoid MNEs' Income Shifting?}

It is necessary to assess how MNEs operate and why their business model has become so predominant and effective in the last two decades, to understand why the arm's length standard imposes a structural limitation on the sourcing of MNEs' income and cannot yield practical results (Avi-Yonah \& Benshalom, Formulary Apportionment-Myths And Prospects: Promoting Better International Tax Policies By Utilizing The Misunderstood And Under-Theorized Formulary Alternative, 2011).

First, MNE groups appear precisely in order to elude the inefficiencies that arise when unrelated companies must transact with one another at arm's length. Basically, MNEs arise due to organizational and internalization advantages relative to the efforts of unrelated, separate companies that seek to do business with one another. These advantages consist of that within MNEs, profit is generated in part by internalizing transactions within the firm. Hence, for firms that are truly integrated across borders, holding related entities within the commonly controlled group to an "arms-length" standard for the pricing of intercompany transactions does not make sense, nor does allocating income and expenses on a country-by-country basis (Avi-Yonah \& Benshalom, 2011).

MNEs have a significant performance in those industries in which the ability to integrate functions in different jurisdictions enables them to reduce certain costs through synergy that takes advantage of economics of scope and scale. These costs include research and development costs, transaction costs, information-obtaining costs, managerial costs, and finance costs. The essence of the MNE structure and an important source of profitability is the ability to efficiently internalize these costs. All MNE entities, which are somehow involved with the activity that produces the benefits, contribute in some ways in this cost reduction process. Hence, the arm's length standard cannot break down the cost of what unrelated parties would have done as the MNE setting is designed specifically to save the costs of doing business through unrelated transactions (Avi-Yonah \& Benshalom, 2011).

Second, as we said before the permeability of existing transfer pricing rules produces an artificial tax incentive to locate profits in low-tax countries, by locating real economic activities in such countries and by shifting profits toward more lightly 
taxed locations. Tax authorities like DIAN require MNEs to report their income in a way that breaks down the cost saving associated with being a MNE on an arm's length basis. However, this requirement cannot be met, proved, or consistently enforced. This intrinsic vagueness motivates MNEs to structure their affairs in a mode that reduces their tax costs (Avi-Yonah \& Benshalom, 2011). Still, MNEs are willing to employ ample resources to defend their aggressive positions (Spencer, 2014).

Finally, another reason is that the arm'slength standard was adopted in a simpler time, when the foreign operations of MNES were moderately self-contained in a foreign country and related party transactions were usually limited (Spencer, 2014).

\section{BEPS Solutions}

\section{Why BEPS for transfers pricing for intangibles?}

The tax avoidance has converted into a significant priority for the OECD (Noked, 2014), which developing the BEPS ratifies the awareness of the income shifting and its negative effects in the national economies (OECD, Action Plan on Base Erosion and Profit Shifting, 2014). The BEPS are a response from OECD to MNEs, which have taken advantage of the globalization and the evolution of the tax regime, maximizing their tax planning by shifting income (Brauner, 2008). The MNEs' value is no longer restricted to brick and mortar assets, however is rather being driven by investment in intangible assets, in order to differentiate them from their competitors. Therefore, MNEs are investing more in developing intangibles as a means of accessing higher returns, because they generate significant income (William, 2014).

Transfer pricing rules apply to any transaction, which involves a transfer of intangibles to a related party. For instance, the analysis of the rules is required in any licensing agreement; in practically each international restructuring of groups of companies; in any intragroup agreements which include knowledge; research and development, management, organizational or production and manufacturing processes; and in the distribution agreements of tangible products where the value of the product depends on proprietary software (Brauner, 2008).

The development of the intangible usually takes place in the United States, whereas the foreign affiliate only contributes with a portion of the development costs. That portion could be a capital contribution, which is received by the subsidiary from its parent. Moreover, the subsidiary is entitled to a portion of the profits from the intangible or to rights to exploit it, if the development is successful. For instance, the American tax rules state that when a U.S. Corporation sells an asset or licenses its use to a foreign affiliate, the sale price, or a royalty rate, must be reported based on the price or royalty that would be expected if the transaction had happened between the U.S. corporation and an unrelated party. Nonetheless, the application of those rules is problematic to situations wherein a U.S. company shifts the rights to its core intangible property to a foreign affiliate. Nonetheless, income-shifting systems work effectively for taxpayers whose profits depend mainly on valuable intangibles (Noked, 2014).

Colombian companies are not significant intangible property developers, yet its economy is growing, thus the income shift- 
ing can be a plentiful problem in the near future. Therefore, it is necessary to learn from the United States and OECD's experience to identify the transactions undertaken by MNEs to reduce their taxable base. The DIAN lags behind what is referred as transfer-pricing audit, and therefore she should tend to strengthen its international audit department, as she is not completely aware of international tax avoidance practices.

Transfer -pricing rules based on arm's length standard permit a variety of alternatives and do not block intangible property income shifting efficiently, because it is barely to find comparable transactions between unrelated parties and the value of assets depends on projected cash flows and a discount rate to account for the associated risk. Essentially, DIAN works with OECD guidelines; yet we can assume that it is not an effective labor, as we almost always lose the cases in the courts based on formal issues.

The BEPS project, the OECD has established three core principles as fundamental for international tax reform: (i) promote of collaboration rather than competition based solutions; (ii) take a systematic holistic view of the challenges and their corresponding solutions rather than a competition-based paradigm; and (iii) permit the consideration of innovative solutions even when they conflict with the traditional premises of the current international tax regime. The BEPS establishes a shift of the paradigm from the existing emphasis on competitiveness and the perfection of competition to a new collaborative international tax regime (Brauner, 2014).

\section{The OECD action plan}

The OECD's BEPS action plan includes 15 action items with deadlines for delivery on
September 15, 2014 or 2015, with a few residual issues scheduled for December 2015. Nevertheless, the objective of this chapter is to analyze the three action plans related to transfer pricing for intangibles, which are: 1. Action Item one "Address the Tax Challenges of the Digital Economy"); 2. Action items eight through 10 ("Assure that Transfer Pricing Outcomes Are in Line with Value Creation") and; 3. Action Item 13 ("Reexamine Transfer Pricing Documentation").

\section{i. Action item 1 ( "Address the Tax Chal- lenges of the Digital Economy”)}

The MNEs as business model can only be profitable by their substantial intangible content in the current digital economy (OECD, Action Plan on Base Erosion and Profit Shifting, 2014). That significance of the intangible property takes a relevant position in cross-border scenario. The digital economy has provided an advantage to MNEs, and the largest MNEs -as Apple, Microsoft and Google- have practiced aggressive tax planning schemes, which affect tax collection in the most important national economies (Brauner, 2014).

In Action I the BEPS project addresses two issues related to e-commerce and intangibles. First, the requirement of a different approach rather than the application of the old doctrine by analogy. Therefore, the OECD is aware of that physical presence cannot be the only trigger of tax jurisdiction, and then the Permanent Establishment (PE) rules need to be adjusted to this principle by a sophisticated approach. Nevertheless, Colombia has not taken an official position, as it is our belief that the OECD's guidelines are infallible. On the other hand, the United States resists to a fundamental reconsidera- 
tion of the PE rules, because the belief is that it would affect principally American MNEs. The United States might wish an Item 1 as a device against the most aggressive tax planning schemes (Brauner, 2014).

The second issue is the current difficulty to valuate intangibles under the arm's length standard. However, the action plan relegates this aspect to items eight through ten which is the transfer pricing part of the plan. Once again, a more sophisticated approach is necessary here as the valuation of intangibles is a challenging exercise because of their unique characteristics (Brauner, 2014). As we said before, Colombia applies the OECD frameworks, even the valuation methods, however, our tax authority has not thought about alternative methods yet, likewise a formulary method.

The Action Item I claims that the current tax rules were not designed for the new economy. Besides, it expresses some concern about e-commerce and intangibles that require a different approach rather than the application of the principle of physical presence, and the need to develop another way to value the intangibles different from the old doctrine of the arm's length principle.

In my opinion, the DIAN is not entirely conscious of the relevance of the digital economy, and how it can be a source of new resources for the government. The DIAN should emphasize on creating conditions for taxpayers to comply with the obligations of revenues generated in the digital economy.

\section{ii. Action items 8("Assure that Transfer \\ Pricing Outcomes Are in Line With Value Creation")}

An aggressive transfer pricing planning practice is the heart of BEPS project. When an intangible is exported to another tax jurisdiction it becomes difficult for the taxpayers to enhance a scheme that uses cost sharing to effectively export the aforesaid foreign rights in their intangible to a low-tax jurisdiction (OECD, Action Plan on Base Erosion and Profit Shifting, 2014). Cost sharing is not an illegal practice, and shields qualified taxpayers from the scrutiny of tax administrations, mainly in the United States. When the intangible is located in the lowcost tax jurisdiction, the MNES would build their business worldwide in a manner that would maximize the profits shifted to these low-tax jurisdictions at the expense of the countries where they operated using numerous schemes (Brauner, What the Beps?, 2014). The cost sharing agreement represents a potential problem for Colombia because it has not measured the consequences of its application. Decreto 3030 of 2013, article 13).

The action transfer pricing item for intangibles is number eight: Develop rules to prevent BEPS by moving intangibles among group members. This will involve: (i) adopting a broad and clearly delineated definition of intangibles; (ii) ensuring that profits associated with the transfer and use of intangibles are appropriately allocated in accordance with (rather than divorced from) value creation; (iii) developing transfer pricing rules or special measures for transfers of hard-to-value intangibles; and (iv) updating the guidance on cost contribution arrangements (OECD, Action Plan on Base Erosion and Profit Shifting, 2014).

Because the arm's length standard is the foundation of the international transfer pricing regime the taxpayer needs to find comparable market transactions between unrelated parties and imitate their pricing in the related party transactions (Brauner, 2008). The applica- 
tion of arm's length standard permits flexibility and inaccuracy and creates an advantage in favor of the taxpayers subject to transfer pricing analysis (MNEs) (Brauner, 2008). The DIAN deals with the complexity of the transfer pricing regime, hence we could claim audits were mostly on formal affairs, but we have been improving our techniques since 2012, when we have endeavored to make substantial audits through the direct consultation of the OECD.

Then, the OECD is promoting the principle of ensuring that profits associated with the transfer and use of intangibles are appropriately allocated (profit split methodology) be in accordance with value creation. This principle is rudimentary, yet one can work with it (The Cost Approach to Valuation). This principle will not be easy to implement, as it might be inconsistent with some other language and current rules. Afterwards, the intangibles project seems to accept more of a central role for a profit split methodology that is significantly formulary (Brauner, 2008). In addition, the cost approach to valuation uses expenditures into the valued intangibles to construct their value assessment (Brauner, 2008). A technical definition cost approach to valuation is:

The cost approach seeks to measure the future benefits of ownership by quantifying the amount of money that would be required to replace the future service capability of the subject intellectual property. The assumption underlying this approach is that the cost to purchase or develop new property is commensurate with the economic value of the service that the property can provide during its live. The cost approach does not directly consider the amount of economic benefit that can be achieved or the time period over which they might continue. This approach is often employed together with the assumption that economic benefits indeed exist and are sufficient amount and duration to justify the development expenditure. (Smith \& Parr, 2006).

The application of the principle of collaboration is mandatory if the OECD wants to be successful in the implementation of the new methodology of evaluation, as the same formula must symmetrically apply to both borders of the transaction. It could help DIAN to improve the compliance of tax obligation by inspection and control.

\section{iii.Action item 13 ("Re-examine Transfer Pricing Documentation”)}

The guidance from the Discussion Draft intended deep changes regarding transfer pricing documentation. First, reaffirming the general rule to demand, report, and exchange all information that is clearly useful for tax inspection and control purpose, but not usually more than that. Moreover, coming up with two important innovations, which are: of (I) a master file containing standardized information relevant for all MNE group members, and (II) a local file referring specifically to material transactions of the local taxpayer (OECD, Discussion Draft on Transfer Pricing Documentation and CBC Reporting, 2014). Certainly, both two documents will be helpful for the DIAN to realize how the MNEs are investing in Colombia with intangibles, and they the starting point for audit activities. Currently, the information presented does not follow any standard and its interpretation is often problematic for the government officers. 
First, the master file will include all the general required information about the structure and operations of the MNE, its intangibles and its financial and tax positions, and must be accessible to all the Tax Administration of the country where the MNE operates and that may have a tax claim over such MNE's income (Brauner, 2014). The information in the master file would be organized into five categories: a) the MNE group's organizational structure; b) a description of the MNE's business or businesses; c) the MNE's intangibles; d) the MNE's intercompany financial activities; and e) the MNE's financial and tax positions. The section of the master file on financial and tax positions includes country-by-country reporting -hereinafter CBCR- of certain information relating to the global allocation of profits, the taxes paid, and certain indicators of the location of the economic activity (tangible assets, number of employees and total employee expense) among countries in which the MNE group operates. It also requires reporting of the capital and accumulated earnings as well as aggregate amounts of certain categories of payments and receipts between associated enterprises (OECD, Discussion Draft on Transfer Pricing Documentation and CBC Reporting, 2014).

Second, the local file will include information about the relevant local entity or entities of the MNE, information related to local transactions, and significant financial information. Further, this file will be available in a standard format with only the local information, in every relevant jurisdiction. Hence, each country might have the option to require additional reporting beyond the standard to complement the local file. Such information would include relevant financial information regarding those specific transactions, a comparability analysis and the selection and application of the most appropriate transfer pricing method for the fiscal year in question (OECD, Discussion Draft on Transfer Pricing Documentation and CBC Reporting, 2014).

Standardizing affirms the principle of collaboration and allows a hand-to-hand effort by tax authorities to apportion tax jurisdictions among them based on an agreed-upon baseline rather than competition based solutions, which are inefficient incentives for both taxpayers and tax authorities to obscure information. Further, standardization is particularly helpful for governments that are weak in comparison to MNE taxpayers and therefore may not alone be able to claim and compel fulfillment at a sufficient level. The standardization also is coherent with all three principles of BEPS: it is innovative, it is comprehensive, and it enhances collaboration rather than tax competition (Brauner, 2014).

Implementing CBRP is important for the substantive reasons of improving compliance and enforcement, but furthermore it may restore the confidence of the public in the international tax regime which a key goal of the BEPS project, hence the significance of legitimacy (Brauner, 2014).

The new taxes documentation is the most powerful instrument in the BEPS as Colombian Tax Authority could audit deeply all taxpayers and encourage their compliance of taxpayers, which works with transfer pricing, because the information will have a comprehensive format. However, the prevalent argument in this regard is the disclosure of confidential information related to the intangible information, yet the Discussion Draft on Transfer Pricing Documentation establishes that the tax administrations should warrant the information (OECD, Discussion 
Draft on Transfer Pricing Documentation and CBC Reporting, 2014), which is an issue about DIAN has been criticized for in the past, like the allegation of revelation of private information.

In conclusion, the BEPS are a breakthrough for controlling operations involving intangibles. The BEPS will be useful for the DIAN's audit activity and the compliance of taxpayers, but also they will help to achieve a comprehensive analysis of the information provided by MNEs. We strongly believe that the collection of taxes for this item will increase from the time of its implementation, and will help to clarify what activities really involve intangibles as sometimes it is not clear for the DIAN.

\section{OECD releases implementation package for beps Country-By-Country reporting}

In October 15 of 2015 it was published the Final Report of the CBCR Implementation Package, which will facilitate a consistent and swift implementation of new transfer pricing reporting standards developed under Action 13 of the BEPS Action Plan, ensuring that tax administrations obtain a complete understanding of the way multinational enterprises structure their operations, while also ensuring that the confidentiality of such information is safeguarded (OECD, Transfer Pricing Documentation and Country-byCountry Reporting ACTION 13: 2015 Final Report, 2015).

The CBCR Implementation Package contains Model Legislation and Multilateral Competent Authority Agreement on the Exchange of reports.

The Model Legislation contained in the CBCR Implementation Package takes into account neither the constitutional law and le- gal system, nor the structure and wording of the tax legislation of any particular jurisdiction. Jurisdictions will be able to adapt this model legislation to their own legal systems, in which changes to current legislation are required. Instead, the Convention on Mutual Administrative Assistance in Tax Matters (the "Convention') requires the Competent Authorities of the Parties to the Convention to mutually agree on the scope of the automatic exchange of information and the procedure to be complied with (OECD, OECD, 2015).

CBCR is a key issue and it essential for more efficient tax enforcement, including enforcement of the OECD's arm's-length standard. The CBCR (with combined reporting) is an essential factor for global formulary apportionment and unitary taxation, which would require calculation of the worldwide income of each multinational, detailed information about its assets and activities in each relevant jurisdiction, and the disclosure of that information, at least to the tax authorities of relevant jurisdictions. Hence, the adoptions of CBCR might be an important first step and facilitate the movement toward formulary apportionment and unitary taxation (Spencer, 2014).

\section{Proposition of alternative tools}

Although Colombia must remain in the OECD frameworks, this chapter analyzes alternative solutions that the Ministry of Finance and the DIAN would implement against income shifting and base erosion in the coming years, which may come from outside of the traditional perspective of the OECD. Implementing these alternative tools by DIAN would be encompassing with the international environment of the need of 
inclusion of internal reforms to prevent all those practices that affect the tax collection, and it should occur after a broad study of their convenience from the legal and economic point of view.

The third principle of BEPS claims the consideration of innovative solutions even when they conflict with the traditional premises of the current international tax regime. That principle is promoting an alternative based transfer regime, beyond the arm's length rhetoric. The language of the action items "hard-to-value intangibles," implies that the current arm's length-based transfer pricing regime is unable to regulate. However, the principle refuses to accept consideration of a replacement for the arm's length-based system at all (Brauner, 2014). This chapter considers that Colombian policymakers should improve the arm's length standard rather than abandon it altogether, because it is not broken beyond repair (Benshalom, 2013).

\section{Formulary apportionment approach}

A recurrent solution in the literature is the formulary apportionment. In 1995, the US adopted new transfer pricing regulations that incorporated two new methods, the Comparable Profit Method (CPM) and Profit Split, which relied much less on comparable (CPM uses comparability very loosely and in Profit Split the residual is not allocated based on comparable). The OECD followed suit and amended the Transfer Pricing Guidelines to include the new methods, which it calls the Transactional Net Margin Method (TNMM) and Profit Split, although in deference to opponents of formulary apportionment the OECD still rejected it and emphasized that the traditional methods were to be preferred to the new ones (OECD, Transfer Pricing Guide- lines for Multinational Enterprises and Tax Administrations, 1995). It also changed the name CPM to TNMM to emphasize that it does not involve a global profit allocation but rather allocation for the particular transaction, since the former is closer to formulary apportionment.

Prof. Reuven S. Avi-Yonah claims that it is clear that by moving beyond traditional comparability, the OECD was moving closer to accepting formulary apportionment (AviYonah \& Benshalom, 2011). He believes that once you do not base the arm's length standard on finding comparables, then it is not very significant to say that a particular method is or is not compatible with the ALS, as if there is no comparable it cannot be proved that the result obtained by that method was not what unrelated parties would have done at arm's length. That is why it is possible to argue that formulary apportionment is compatible with Article 7 of the OECD model treaty, which focuses on the results that unrelated parties would have reached and permits in Art. 7(4) the use of formulas as long as the result is compatible with the arm's length standard.

Avi-Yonah suggests a new model where there is not comparable under the arm's length standard. This method would be a version of formulary apportionment, which, in essence, is a residual profit split with the residual split based on the U.S. traditional state formulary factors of payroll, tangible assets, and sales (Avi-Yonah \& Benshalom, 2011).

Besides, he argues that these three components are of course the traditional U.S. state formulary apportionment formula. This formula has confirmed to be remarkably efficacious, since in addition to the U.S. states, it is also the basis for the global dealing regulations in the U.S. and OECD, 
and it is a leading candidate for the Common Consolidated Corporate Tax Base (СССТВ) formula. He believes that it makes sense because each of its elements is objective (payroll and sales are transactions with outside parties, and while tangible assets depend on valuations, there is a lot of experience with asset based formulas, such as the U.S. interest allocation formula). Intangibles are excluded, but in his opinion that is appropriate because (a) their value results from physical and human capital and from the market and those elements are included, and (b) you cannot allocate their value and trying to include them invites manipulation.

Moreover, he would propose that in hard transfer pricing cases, in which no comparable can be found beyond the return on routine functions, the OECD endorses using the traditional three factor state formula to allocate the residual under the Profit Split method.

The DIAN and Colombian Ministry of Finance should carefully analyze this approach. In order to decide whether or not is viable to enforce unilaterally a formulary apportionment; the Colombian government should attempt a legal analysis in the context of its international affairs with the OECD.

\section{Recharacterizing intra-group equity investments as a type of long-term subor- dinated debt.}

Professor Ilan Benshalom argues (Benshalom, 2013), that the arm's length standard literature demonstrates that the weakness of all transfer pricing regimes includes intangible related transactions and debt financing. In his opinion, one of the main sources of weakness of the arm's length standards is their failure to characterize intra-group equity investments, which are, by definition, "related" as long as they provide control over a subsidiary. That makes dividend payment discretionary, as parties can elect how and when to make them. This payment option is opposing to the arm's length standard, which tries to prevent MNEs from manipulating their tax liabilities by requiring them to price intra-group-related transactions as if made between unrelated parties.

The arm's length standard creates an ambiguity, because tax authorities cannot enforce an unrelated setting on control-equity investments, as in a real market setting where there is a natural competition between parties, so no one would "just decide" to transfer dividends (money) to unrelated parties. As result, MNEs take advantage from this ambiguity and design their financial structures in a tax-optimal way that permits them maximum control over the timing, character, and amount of intra-group payments.

The Professor suggests that the answer to intra-group equity investments might be establishing a policy that requires that the transfer be characterized as long-term subordinated debt. When one "unrelated" party transfers assets to another without any explicit collateral or guarantee of return, the transfer should be characterized as long-term subordinated debt.

These interest payments should be imputed, because no interest payments may actually take place. The solution of how much, when, and what type of income (and deductions) should result from MNEs' investment transactions under an arm's length standard framework. Financial markets are far from perfect in pricing interest rates, but they yet do so by relying on relatively well- 
known and easily observable features (e.g., overall leverage, cash flow, tangible assets, risk associated with commercial activities, and firm- and country-specific risks). Correspondingly, tax authorities can accurately and almost costlessly determine the appropriate interest rate for long-term subordinated loans based on readily available market information.

Finally, Benshalom concludes that this sourcing would improve the current system by using the arm's length standard in a way that offers a more accurate accounting of the amount of income generated in each jurisdiction and would require that MNEs more consistently time and characterize different payments.

In this approach, we can arise at the same conclusion that the Colombian government should analyze prudently the option of implementing tools which are not expressly contemplated in the OECD frameworks, yet could harmonize with the arm's length standard.

\section{Conclusions}

The paper is demonstrating that the current international transfer pricing rules are not appropriately adapted to the new digital economy. Under the arm's length regime the valuation of intangibles results in a high level of compounded inaccuracy.

Colombia is no stranger to the international context in the application of the arm's length standard, and its Tax Administra- tion is facing the same difficulties with the enforcement of the arm's length standard, thus, the DIAN could be confronting the same sophisticated tax avoidance methods of multinationals, which create an inequity when they shift their tax payments in low tax jurisdictions.

The paper has proven that the arm's length standard is not workable, and we propose have some steps that can be taken by the DIAN. First, the implementation of BEPS' tools, like "Country-by-Country Reporting Implementation Package", will be useful for DIAN's audit activity and the compliance of MNES taxpayers, but also they will help to achieve a comprehensive analysis of the information provided by MNEs. However, the DIAN should make an additional effort to provide clear rules related to the application of transfer pricing, and its use by MNEs to shift income from the Colombian tax jurisdiction.

Second, in the coming years the Colombian government should carefully analyze the alternative approaches formulated by the literature to fight against income shifting and tax avoidance. So as to arise whether or not is viable to enforce unilaterally a formulary apportionment or the recharacterization of intra-group equity investments as a type of long-term subordinated debt -among other innovative possible solutions- the Colombian government should attempt a deep legal and economic analysis, and try to figure out the possible consequences of that implementation. 


\section{References}

Avi-Yonah, R. S., Clausing, K. A., \& Durst, M. C. (2009). Allocating Business Profits For Tax Purposes: A Proposal To Adopt A Formulary Profit Split. Florida Tax Review.

Altshuler, R., \& Grubert, H. (2010). Formula Apportionment: Is It Better than the Current System and Are There Better Alternatives? National Tax Journal.

Avi-Yonah , R. S. (1995). The rise and Fall of arm's length: A study in the evolution of U.S. international taxation. Virginia Tax Review.

Avi-Yonah , R. S., \& Benshalom, I. (2011). Formulary Apportionment-Myths And Prospects: Promoting Better International Tax Policies By Utilizing The Misunderstood And Under-Theorized Formulary Alternative. World Tax Journal.

Benshalom, I. (2013). Rethinking The Source Of The Arm's-Length Transfer Pricing Problem. Virginia Tax Review.

Brauner, Y. (2008). Value In The Eye Of The Beholder: The Valuation Of Intangibles For Transfer Pricing Purposes. Virginia Tax Review.

Brauner, Y. (2014). What the Beps? (D. M. Hudson, Ed.) Florida Tax Review.

DIAN. (2012). Transfer Pricing Guidelines. Bogota: DIAN. Retrieved from http://www.dian.gov.co/descargas/ Formularios/2013/precios_transferencia_2012.pdf

Levey, M. M., \& Wrappe, S. C. (2013). Transfer Pricing: Rules, Compliance and Controversy (4th ed.). Wolters Kluwer.

Lowell , C. H., \& Briger, P. L. (2014). U.S. Internacional Transfer Pricing. New York City, Estados Unidos: Thomson Reuters Tax and Accounting.

Morse, S. C. (2010). Revisiting Global Formulary Apportionment. Virginia Tax Review.

Mundstock, G. (2012). The Borders of E.U. Tax Policy and U.S. Competitiveness. University of Miami Law Review.

Noked, N. (2014). Integrated Tax Policy Approach To Designing Research \& Development Tax Benefits. Virginia Tax Review.

OCDE. (2010, July 22). Review of Comparability and of Profit Methods: Revision of Chapters I-III of the Transfer Pricing Guidelines. Retrieved from http://www.oecd.org/ctp/transfer-pricing/45763692.pdf

OECD. (1995). Transfer Pricing Guidelines for Multinational Enterprises and Tax Administrations. Paris: OECD. OECD. (2010). Transfer pricing Guidelines for multinational Enterprises and Tax Administration. Paris: OECD.

OECD. (2014). Action Plan on Base Erosion and Profit Shifting. Retrieved Junio 2015, from http://www.oecd. org/ctp/BEPSActionPlan.pdf

OECD. (2014). Discussion Draft on Transfer Pricing Documentation and CBC Reporting. Retrieved from http:// www.oecd.org/ctp/transfer-pricing/discussion-draft-transfer-pricing documentation.pdf

OECD. (2015). Country-by-Country Reporting Implementation Package. Retrieved from http://www.oecd.org/ ctp/transfer-pricing/beps-action-13-country-by-country-reporting implementation-package.pdf

OECD. (2015). Ministerial Council Meeting. Retrieved from http://www.oecd.org/mcm/ 
OECD. (2015). OECD. Retrieved from http://www.oecd.org/ctp/transfer-pricing/beps-action-13-country-by-countryreporting-implementation-package.pdf.

OECD. (2015, October 5). Transfer Pricing Documentation and Country-by-Country Reporting ACTION 13: 2015 Final Report. Retrieved October 10, 2015, from OECD.org: http://www.oecd.org/tax/transfer-pricing-documentation-and-country-by-country-reporting-action-13-2015-final-report-9789264241480-en.htm

Smith, G. V., \& Parr, R. L. (2006). Intellectual Property: Valuation, Exploitation, and Infringement Damages. Hoboken: John Viley \& Son, Inc.

Spencer, D. (2014). Formulary Apportionment Is Not A Panacea (Part 1). Journal of International Taxation.

Well, B., \& Cym, L. (2014). Tax Base Erosion: Reformation of Section 482's arm's length standard. Florida Tax Review.

William, M. (2014). U.s. Issues Valuation Ruling on Exclusive Distribution Rights; Concept Debate Continues At Wco. Journal of International Taxation. 